\title{
Telecommunications and International Trade Contracts: Resolving Matters Arising for Optimal Utility
}

\author{
Miebaka Nabiebu* Enyia, Jacob Otu** \\ *Doctoral Candidate \\ University of Calabar, Nigeria \\ ${ }^{* *}$ Senior Lecturer, Department of Commercial and Industrial Law Faculty of Law, \\ University of Calabar, Nigeria \\ ${ }^{*}$ Corresponding author's email: joenyia [AT] unical.edu.ng
}

\begin{abstract}
This paper examines the impact of telecommunications on international trade contracts and the associated telecommunications regulatory issues that inhibits optimal utility. It also examines matters arising out of global telecommunications trade, and advanced recommendations for optimal utility of telecommunications in international trade contract. In doing this, the paper $x$-ray the import of telecommunications in international trade contract, some conventions and laws in relation to international trade, basic principles and contents of international trade contracts in telecommunications, matters arising and the future of telecommunication contracts.
\end{abstract}

Keywords--- Telecommunications, international trade contracts, utilitarian value, digital age, regulatory issues, dispute resolution, economic development

\section{INTRODUCTION}

The telecommunication sector plays an important role in the global economy, connecting people, businesses, government and markets. Telecommunications services are instrumental in dissemination of information to the world, which in turn contributes to economic growth and financial stability, disperses knowledge on global issues and problems which raises political and cultural awareness. Hence, a well-functioning telecommunications sector provides a foundation for other economic activities and is a key economic activity. ${ }^{1}$ The main purpose of having a global telecommunications trade is to encourage and support telecommunications cooperation among nations.

Technologies can serve not only to foster economic development, democracy and political stability but also to balance these processes so as to make them more mutually, reinforcing. Moreover they can help develop countries, reinforce national and local communities while at the same time foster their global integration. Advance technology plays a huge role in engendering social, economic and political impacts. It also helps in developing a data base and networks for policy collecting and disseminating aid-related criteria information and results. It also aid developing countries to further become integrated into the world economy. ${ }^{2}$

Telecommunication service trade includes transactions that cross national border, such as telephone calls or electronic mails sent from one country to another. It also covers foreign investments such as the purchase of telephone. It also covers foreign investments such as the purchase of telephone companies by foreign or joint ventures between local and foreign partners to establish new telecommunication service companies. One of the most important ways in which telecommunications services are traded in through foreign investments to establish commercial presence. ${ }^{3}$ A new paradigm based on global competition is emerging for international trade in telecommunications. It recognizes that trade in telecommunication equipment and services now takes place in a multilateral environment in which the majority of trade relationship includes intermediaries between buyer and seller. ${ }^{4}$

The trade rules that apply to telecommunications services include the framework articles of the General Agreement on Trade in Services (GATS) which contain the principles for trade in all services. In addition, the GATS also contains an "Annex on telecommunications". This provides guarantees for reasonable access to and use of public

\footnotetext{
${ }^{1}$ ITU World telecom/ICT Database. See also, "World Bank, 2006 information and communications for development, Global Trends and Policies" at 5.

${ }^{2}$ Karie Hoff, \& Ors (eds) the Economics of Rural Organisation (New York: Oxford University Press, 1993).

${ }^{3}$ Trade in telecommunications. World telecom development report 1996/1997. Forum 1998, Geneva 16-18 March, https://www.ituint/news.org

${ }^{4}$ Enyia, J.O; Telecommunications Law \& Practice in Nigeria: Perspective on Consumer Protection, Lagos: Malthouse Law Books, 2018, p.222.
} 
telecommunications in a given market, by suppliers of all services benefiting from element commitment scheduled by the member concerned. Another key, which is the "Reference Paper" is a set of regulating principles that is legally binding for those world trade organisation (WTO) governments which have committed to it by appending the document in whole or in part, to the schedules of commitment. ${ }^{5}$

Trade agreements regulate international trade between two or more nations. Several general trade agreements have shaped trade policy on broad levels. The most important general trade agreement is called the General Agreement on Tariffs and Trade (GATT). GATT was signed to liberalize trade, to create an organisation to administer more liberal trade agreements, and to establish a mechanism for resolving trade disputes. To a large degree, the role of GATT as an organisation has been superceded by the World Trade Organisation. ${ }^{6}$ This paper also covers International Trade in Telecommunication, Preparation of International Trade Contracts, and the Impacts of Telecommunication in International Trade Contracts.

\section{INTERNATIONAL TRADE IN TELECOMMUNICATIONS}

International trade in telecommunications can be defined as sales of telecommunication equipment or services that cross national borders. The imports and export of telecommunication equipment conforms well to our traditional understanding of trade as buying and selling.

Export now accounts for about one-third of the total telecommunication equipment market and that share continues to rise steadily. This boom has been largely driven by the growth in the demand for telecommunication services which in turn is driven by the construction and modernization of network. ${ }^{7}$ Traditionally, international telecommunication agreement opens the way to a multilateral framework for free trade, market opening and competition. This report tracks the evolution from an old regime of international telecommunications to a new regime of global competition. ${ }^{8}$ Until recently, opportunities for telecommunication services trade had been more limited than for equipments. Telecommunication service trade includes transactions that cross national borders, such as telephone calls or electronic mail sent from one country to another. It also covers foreign investment such as, the purchase of telephone companies by foreign investors or joint ventures between local and foreign partners to establish new telecommunication service companies.

\section{DOES TELECOMMUNICATIONS TRADE MATTER?}

Trade in telecommunications matters for many reasons: firstly because the telecommunication industry is a significant and growing sector in its own right. In terms of market capitalization, the telecommunication industry ranks third in the world behind health care and banking, while telecommunication and office equipment was the fastest growing sector of merchandise exports in 1995. Secondly, because telecommunications plays an important role for other industries. Information and the facilities for accessing, processing and disseminating it in electronics form, have become a strategic resource as important as land, labour and capital. Thus, telecommunication has a dual role as both a traded product and service, and as a facilitator of trade in other products and services. ${ }^{9}$

The industry is growing stronger as well as faster. In 1995, the average expenditure by telecommunication users rose by almost US \$ 100 to US \$ 905. Equally, the volume of international tariff which they generate rose up by 5 per cent to 89 percent each per year, providing a further boost to global trade and tourism. Furthermore, the telecommunication sector is at the heart of a much larger industry-information and communications, or info - communications - worth some US \$ 1,370 billion in 1995 . The convergence of the telecommunications sector with the computer and broadcasting world is creating new synergy, most evident in the growth of the internet, which continues to double in size every year. ${ }^{10}$

Telecommunications today constitute an important factor in granting access to and expanding markets, particularly at the international level. Those who cannot gain access to good network and services will be moved and more excluded from international markets. Telecommunications are essential today for the supply of commercial services regarded as normal in more and more markets. Those who do not know how to utilize them will soon become uncompetitive. ${ }^{11}$ Also, telecommunication infrastructure, network and services thus constitutes, from the stand point of the development of world trade, an essential economic resource and a necessary condition for entering and competing on international markets. Any production process today entails the mobilization of large amounts of information. Any

\footnotetext{
${ }^{5}$ World trade organisations: telecommunication services-sector by sector. Applicable rules, www.wto.org

${ }^{6}$ Ibid.

${ }^{7}$ World telecommunications development report 1996/1997 forum98, Geneva 16-18 March. What is trade in telecommunications. https://www.itu.int/ne'ws.org

8 Ibid

${ }^{9}$ Ibid

${ }^{10}$ Ibid

${ }^{11}$ Carol Moreira. United Nations Conference for trade and development. UNCTAD (telecoms: A key resource for international trade), www.arravder.com
} 
commercial transaction similarly requires the circulation of many items of information. The product sold, whether goods or services, contains added value in the form of information which is growing from year to year. ${ }^{12}$ In developed economies, between 40 and 60 per cent of the labour force is employed in producing, processing or communicating information. Moreover, it is regarded as the key resource for international trade in goods and services. The international community has, moreover, recognized this quite clearly. Like any resource, telecommunications are rather scarce and can be used to better or worse effects. ${ }^{13}$ When properly dimensioned (in terms of its nature, volume and price), the telecommunications resource can improve the flow of international trade. When properly used (in terms of cost and applications), it can increase the value added to the trading activities beyond the transaction itself. There is today an unprecedented opportunity to base the development of international trade on intensive use of efficient telecommunications. ${ }^{14}$

\section{CONVENTIONS AND LAWS ON INTERNATIONAL TRADE CONTRACT}

The United Nations Convention on the use of Electronic Communications in International Contracts (the "Electronic Communications convention" - ECC), is a treaty that aims at facilitating the use of electronic communications in international trade. It was prepared by the United Nations Commission on International Trade Law (UNCITRAL) and adopted by the United Nations General Assembly on 23 November 2005. ${ }^{15}$ The Electronic Communications Convention addresses different policy goals; it removes obstacles arising from formal requirements contained in other international trade law of treaties, it provides a common substantive core to the law of electronic communication, thus ensuring a higher level of uniformity both in the legislative text and in its interpretation, and it provides core legislation on electronic communications to those states not having yet any, or having partial and insignificant provisions. ${ }^{16}$ ECC applied if the law applicable to the communications is the law of a state party to the ECC or if the parties have validly chosen it as the law applicable to their communications.

According to Article 4(b) of the ECC, "Electronic Communication" means any communication that the parties make by means of data message. The notion of electronic communication encompasses the use of different technologies, including, e.g., SMS but also digital audio and video recording. Parties may vary or derogate from any provision of the convention under Article 3. This is a provision common in international trade law treaties, where freedom of contract is considered an overreaching principle. However, in practice, there might limit the freedom of the parties. ${ }^{17}$ One major goal of the Electronic Communication Convention is the removal of obstacles to international trade arising from the insertion of formal requirements in treaties concluded before the broad adoption of electronics means. Article 20(2) of the ECC indicates that the convention will apply also to all other treaties where the exchange of electronic communication is relevant, unless a stage declares not to be bound by this provision. Even if this "opt out" declaration is made, the declaring state may still choose, under Article 20(3), certain treaties to which the ECC will apply. The Electronic Communication Commission aims at facilitating the use of electronic communications in international trade by assuring that contracts concluded and other communications exchange electronically are as valid and enforceable as their traditional paper-based equipment. ${ }^{18}$

The Electronics Communication Convention is an enabling treaty whose effect is to remove those formal obstacles by establishing equivalence between electronics and written form. The convention may provide those countries not having yet adopted provisions on electronic commerce with modern uniform and carefully drafted legislation. Also, the convention is intended to strengthen the harmonization of the rules regarding electronic commerce and foster uniformity in the domestic enactment of UNCITRAL model laws relating to electronic commerce, as well as to update and complement certain provisions of those model laws in light of recent practice. ${ }^{19}$

The US trade Act has longed encouraged active trade of it's goods and services with other countries. It is focused on promoting foreign trade, challenging unfair practices in import trade, blocking the import of countries, it goods in order to protect American trade marked goods and implementing tariffs on foreign products offered to the US market at an unfairly low price. ${ }^{20}$ As the 1974 Trade Act was discussed in the mist of domestic upheaval and the increasingly protectionist attitudes of industries imparted by strong interaction competition such as automobile, steel and consumer electronics like telephones and computers the Us entered into the seventh GATT. The round began in 1973 with a strong

\footnotetext{
12 Ibid

13 Ibid

14 Ibid

${ }^{15}$ United Nations Convention on the use of electronic communications in international contracts (New York, 2005). En.rn.wkipedia.org

${ }^{16} \mathrm{Ibid}$

$17 \mathrm{Ibid}$

${ }^{18} \mathrm{UN}$ convention on the use of electronic communications in international contracts. Uncitral.org.

${ }^{19}$ Ibid

${ }^{20}$ Sharon K. Black, pg. 199. Telecommunication Law in the Internet Age (2002) Morgan Kaufman Publishers.
} 
agenda to reduce tariffs, technical trade barriers, antidumping and custom valuation ${ }^{21}$

The Telecommunication Trade Act 1988 is a short Act containing only 10 sections that focus on creating opportunities for telecommunications in the world market. It codified the concept leading to the WTO and the addition of services to the General Agreement on Tariffs and Trade (GATT). The Act requires that the US Trade representative review each year the operation and effectiveness of every trade agreement regarding telecommunication products or services that it in force with respect to the US. It also declares any act, policies of a country that deny telecommunications products and services of US firms mutually advantageous market opportunities in foreign country will be challenged by the US government. $^{22}$

Other trade laws include the North American Free Trade Agreement Implementation Act of 1993 with it's main objective to open free trade in telecommunication goods, services and capital. It established a model for the WTO. The Urugaul Round Trade Agreement opened the largest telecommunication market industry. It created the WTO and added services GATT. It encouraged participation in the increasing world market. ${ }^{23}$

The Export Administration Act Of 1979 has three main US objectives:

To restrict the export of goods and technology which would make a significant contribution to the military potential of any other country and prove detrimental to the interest of the US, to restrict exports where necessary to further significantly the foreign policy of the US or fulfill its declared international obligation and to protect the domestic economy from excessive drain of scarce materials and to reduce the serious inflationary impact of foreign demand.

Telecommunication providers and users have some of these agencies regarding trade. They include the international trade commission, the international trade administration and the US trade representatives. Awareness of the agencies and their primary roles is essential to telecommunication companies in licensing and complying with the details of the law. The international trade commission (ITC) was created by congress in trade Act of 1974. It was directed to evaluate whether imports posed any injury or threat of injury to US. The ICT publishes reports on the results each year which are particularly important to tracking global telecommunication issues and markets. ${ }^{24}$ The International Trade Administration in the department of commerce implements US import laws. It is also responsible for tracking the impact of countervailing and antidumping duties and determining the fair market values of sales. Based on the international trade administration's findings, duties are imposed on imported goods. This office is particularly useful to the telecommunication industry in tracking competitive prices, practices and market opportunities for US companies. ${ }^{25}$ The US trade representative is so named because she represents the US international trade negotiations. It works closely with the congress, the president and all the agencies and committees involved in US international trade issues.

In the trade Act of 1974, congress established the office of the US trade representative to track US trade opportunities and to report to congress annually on issues such as; anticipated trade levels for the next year, foreign barriers to market access by US firms and inadequate foreign protection of US intellectual property rights. The representative monitor imports to determine if any have harmed US companies or violated the US antidumping and countervailing rules. If any import have the US trade representatives drafts the US response to the offending countries. She also imposes sanctions on countries that unfairly interfere with US exports. In fact her work has been especially valuable to the telecommunications industry in opening the strengthening markets for products and services. ${ }^{26}$

\title{
5. PRINCIPLES OF DRAFTING INTERNATIONAL TRADE CONTRACTS AND CONTENTS
}

A key principle in drafting international trade contract is negotiating and drafting contracts. Negotiating a contract is very important. By negotiating contract terms, the parties to the contract bargain for their best interests. While negotiating contracts, it is important to remember the following: parties should be comfortable with their duties and obligations, the intentions, requirements and expectations each party has to the other party needs to be clear at the beginning of negotiations and Negotiation for a remedy within the contract in the event where there is a breach by either party may save time and expenses, down the road. ${ }^{27}$

The start-up of export or import operation requires the consent of the two parties. This agreement takes shape generally by means of a sale contract, which aims at dividing the expenses and risks between the seller and the buyer. The draft of its contract is of prime importance because it facilitates trade and exchange and especially avoids disputes. ${ }^{28}$ When drafting a contract, it is important that each party know exactly what is expected of them. If there are any words that could be misconstrued or any terms that are ambiguous, parties should be sure to define them within the contract. Ultimately,

\author{
21 lbid pg. 202 \\ 22 Ibid pg. 203 \\ $23 \mathrm{Ibid}$ \\ 24 Ibid \\ $25 \mathrm{Ibid}$ \\ 26 Ibid \\ 27 Matthew 122i. (2014) "contracts drafting and reviews" www.legalmatch.com \\ ${ }^{28}$ Alpha international trade, "preparing international trade contracts" www.alphainternationaltrade.com.
}


when drafting a contract, clarifying the terms and duties should be the goal. ${ }^{29}$ It may sound obvious but before signing a contract, each party should read it. In reviewing the contract, parties need to make certain they understand the stated obligations under the contract. If there is any uncertainly as to the duties of each party and yet they signed the contract, they may be liable for breaching the contract. Having a legal professional review the contract terms will ensure that the needs of each party will be met and that no party will obligate themselves unexpectedly. ${ }^{30}$

\section{a) Contents of International Trade Contracts}

The legal formality for international trade contract must contain some of the following contents: name and address of parties of the contract; the aim of the contract, transport modalities; the price; nature of contract; Guarantee; force majeure; jurisdiction; modalities for delivery; language; the date of the contract; when the contract will take effect; duration of the contract; how the recipient will evaluate the finished product; payment arrangement; contractor's specific duties and deadlines (where applicable); Also, method of communication; confidentiality clause; dispute resolution methods; indemnity clause; limitation of liability clause; choice of law; termination on solvency clause; provision for terminating the contract; signature and date. ${ }^{31}$

\section{BENEFITS AND IMPORTANCE OF INTERNATIONAL CONTRACTS AND TELECOMMUNICATIONS}

Free trade in telecommunication promises to deliver at least 3 economic gains: new improved products and services, lower prices and additional investment. Open trade in telecommunication services should result in more competition, lowering prices for most businesses and for many consumers and providing both with a choice of different service providers. ${ }^{32}$ For many telecommunication users, the transition to a multilateral trading system will bring benefits in terms of greater choice and lower prices. For the majority of carriers, there will be significant benefits in terms of creating new market opportunities and a more level playing field. The goal is to extend the multilateral solution in which all countries move forward together and in which all benefit, not just those carriers with market power. Only then will the benefit of goal competition be extended to all the world's inhabitation. ${ }^{33}$ Telecommunications forms an essential infrastructure for new trade efficiency. Combined with the improved performance on the part of the transport and financial systems, to which they also contribute, the use of telecommunication not only increases trade efficiency, but is actually becoming essential in order to provide the minimum commercial services demanded by markets. Fax, which has supplanted and improved on many functions of telex, cellular radiotelephones and paging are used daily by thousands of people involved in international trade, who find in these services a means of remaining in contract either with their base or with their clients, wherever they maybe. ${ }^{34}$

Again, international trade is surely an area that can be beneficial particularly from the manifold advantages offered by electronic transmission of trade documents, and hence the use of telecommunication networks, requires prior computerization of the document within each link of the chain. Here, the suppliers of efficient telecommunication services can speed up internal computerization by bodies and firms concerned with foreign trade by demonstrating the additional advantages of a computerization services. ${ }^{35}$ Properly used telecommunication networks should help bring down the costs of commercial transactions. Telecommunications can constitute the matrix of economic organisations oriented towards constant gains in efficiency. In many cases, large industrial or trading organisations have already introduced extensive use of telecommunication networks and services around the world. Their size, their multinational presence and the diversity and extent of their markets lead them to take the fullest possible advantages of innovations in the world of telecommunication. Properly managed telecommunication services should increase the value added of the activity of trading in goods and services. ${ }^{36}$

\footnotetext{
${ }^{29}$ Matthew 122i. (2014) "contracts drafting and reviews" www.iegalmatch.com

30 Ibid

${ }^{31} \mathrm{lbid}$

32 World telecommunications development report 1996/1997 forum98, Geneva 16-18 March. What is trade in telecommunications. https//www.itu.int/news.org.

$33 \mathrm{Ibid}$

${ }^{34}$ Carol Moreira. United Nations Conference for trade and development. UNCTAD (telecoms: A key resource for international trade), www.arravder.com

35 Ibid

${ }^{36} \mathrm{Ibid}$
} 


\section{ASSOCIATED INHIBITIONS OF TELECOMMUNICATIONS IN INTERNATIONAL TRADE CONTRACTS.}

The constraint on wide use of telecommunications resources leading to problems of accessibility represents the first type of inequality capable of leading to a dis-functioning of international trade. Thus, exclusion from telecommunications use may constitute a barrier to participation in international trade activity. Second, in many cases, large industrial and trade organisations have already introduced extensive use of telecommunications networks and services around the world into their activities. Their size, their multinational presence and the diversity and extent of their markets lead them to take the fullest possible advantage of innovations in the world of telecommunications, even in contexts where the supply of networks and services is limited, because they can put into operation efficient private network on basic infrastructures. Small and medium sized enterprises, on the other hand, rarely have access to the services and can thus be at a particular disadvantage as regards access to markets. Third, the introduction of the competitive element in the context of technological innovation has certainly resulted in a relative decline in the price of international telephone calls. But it has also speeded up the rate of introduction of new services, creating effects of competition between services and making purchase and use, more problematic.

Fourth, telecommunications are often subjected to high taxes on the various tariff components, particularly calls and direct or indirect levis can weigh heavily on their capacity for self-financing. Uncertainty about government attitudes, the substantial variations that can occur in telecommunication taxes and government levies are all factors preventing the development of uses, either directly because of high elasticity, or indirectly, through operating agencies abilities to invest.

Moreover, inequality in relation to the basic services: today, telephone network acts as the medium for many categories of services. While the technologies used are for the most part electronic, the services offered by telephone networks all over the world are still analogue (telephone, fax, modern data transmission, etc.).

Furthermore, access to telephone networks: access to telephone network is very unequal from one country to another. There may be other physical barriers limiting the use of telephone networks such as incomplete network automation and a manually operated telephone services means that they cannot offer the same quality, nor offer the same functions as an automatic network. Apart from much greater delays in setting up calls, it is often difficult or even impossible to transmit faxes correctly.

Telephone is a basic and essential tool for international trade. As universal services, they are already a feature of any transaction. But for the last 15 years or so, telecommunications have offered a whole range of more highly developed services. Access to these services which meets the needs of modern economies is still very unequal (availability and cost), although they already represent opportunities for increased efficiency in international trade.

\section{MATTERS ARISING OUT OF GLOBAL TELECOMMUNICATION TRADE}

Export and import; Laptop computers, wireless phones and pagers are such common tools in business today that many international business travelers routinely carry the equipment with them as they travel to foreign countries. ${ }^{37}$ What most international travelers do not realize is that by simply carrying these items from country to country, they are exporting and re-exporting products controlled by US trade laws ${ }^{38}$ Most people think of exports as only the sale of equipment to foreign buyers in actuality, any movement of hardware software or data across international borders is an export. Examples overseas data links, files transfer from US internet servers, and the receipt of facsimiles while Abroad are considered exports. Export also occur whenever technology is released to a foreign person. The congress many years ago realized that the technology used to create a product is as important to US interest as the product itself. Thus, the export of technology is as closely controlled as the export of products and services.

Activities performed in the US, without ever crossing a border or conducting a sale can be deemed to be exports. For example providing goods to or sharing technological knowledge with a foreign national in the United State can be an export. This simply means export can occur in the course of technical meeting the sharing of product literature with potential customers, telephone conversations fax transmission, data transfer, email etc.

\section{Dispute Resolution}

Trade contract should delineate what process will be used to resolve any disputes concern the contract if they come up. ADR processes could be used e.g. Arbitration, mediation etc. This is especially important in telecommunication contract because of the varied products and services, the short timeframe and the importance to ongoing communications. Each helps telecommunication companies to move forward to resolve issues.

\section{Licensing Requirement}

For all export one of the two types of licenses issued by the Bureau of export administration (BXA) is required: a general or a validated license.

General license: It is the most common type of license granted for US exports authorizing items to be exported under normal conditions. Most telecommunication product fall under this category. No application is required by

\footnotetext{
${ }^{37}$ Sharon K. Black op. cit. pg. 197.

38 "Congress findings", supra note 1, US Export Administration Act Pub. L. 92-97 Sept. 20,1972, 93 Stat. 503; Pub. L. 99-64, title 1,102 July 12 1985, 99 Sat. 120; codified at 50 USC 32401 (1988).
} 
government to obtain a general license. Validated licenses: Where an export does not qualify for a general license under the Export Administration regulation, then a validated license is required. A validated license is required only in a limited number of export situations and thus only five main types of validated licenses exist. Individual, Distribution, Project, Chemical and Service supply.

Validated licenses requires that a written application with supporting documentation be filled with the Department of commerce's office of export Licensing (OEL). Validated licenses are not automatically granted to the exporter and can be denied in whole or part to remain consistent with the purpose of the export regulation. ${ }^{39}$

\section{Country List}

The US restricts trade with countries listed on the commodity control list maintained by the US department of commerce. Each country is ranked according to an analysis of the political military risk the country poses to the US. It is a preliminary screening of countries, not individuals to whom the exporter is exporting. ${ }^{40}$

\section{Table of Denial Order}

The Department of commerce also maintains a table of Denial Orders listing both individuals and companies that are barred from trade with the US because of past infraction of trade Law.

\section{Choice of Law and Jurisdiction}

The United Nations Convention on contracts for the International Sales of Good (CISG). International contract must also state whose national law will govern the contract, usually each party want its own national law to apply but is negotiable. If parties include a US company or the foreign subsidiary of a US company, the contract is automatically subject to US Law.

\section{TARGET TOWARDS A MULTILATERAL TRADE FRAMEWORK}

A new paradigm is emerging for international trade in telecommunications. The old paradigm, which might be loosely described as "inter-national" telecommunications, was based on bilateral relations between countries. The monopoly operators in those countries collaborated in the joint provision of international services. This model is now breaking down, not so much because the system is not working, but rather because it now fails to capture the full picture. A new pattern based on global competition is emerging. It recognizes that trade in telecommunication equipment and services now takes place in a multilateral environment in which the majority of trade relationships include multiple intermediaries between buyer and seller. We are moving from a world of one-to-one relations to a world of many-tomany. It is not nations that trade with other nations, but companies and individuals that conduct trade with each other. ${ }^{41}$

For many telecommunication users, the transition to a multilateral trading system will bring benefits in terms of greater choice and lower prices. For the majority of carriers, there will be significant benefits in terms of creating new market opportunities and a more level playing field. The goal is to extend the multilateral solution in which all countries move forward together and in which all benefit, not just those carriers with market power. Only then will the benefit of global competition be extended to all the world's inhabitants. ${ }^{42}$

\section{RECOMMENDATIONS}

Some Measures for the Improvement of telecommunications Services for International trade Contracts for Optimal Utility among others include;

First, measures relating to access to telecommunication network: These are measures concerning infrastructures and often entail investment whose impact can only be gradual. This involves raising networks to a level of a geographical and functional development, development of network access in remote or low density regions for small business users through the adaption of appropriate network architectures, development of alternative solutions for ensuring general access to international networks. E.g. access to future low orbit satellite networks, liberalization of international transit centers so as to offer international connections which do not necessarily depend on the state of the trunk networks. ${ }^{41}$

Secondly, measures relating to telecommunications network tariffs: These measures based essentially on tariffs restructuring to reduce the differentials between residential and business users and eliminating discrimination in international calls, production in the cost of international calls with the aims of standardizing international tariffs on the basis of the current average world prices, abolition of special subscriptions for international services, introduction of general automatic access to international services without discrimination, reduction in network cost, abolition of discrimination by type of users, abolition of connection costs for specific terminals, limitation of taxes imposed on various tariff components of telecommunications and limitation of state levies on the telecommunication operating agencies income.

Thirdly, measures relating to non-tariff obstacles: include abolition of specific arrangements for access to international networks and services through general standardization of procedures for commercial interconnection between domestic

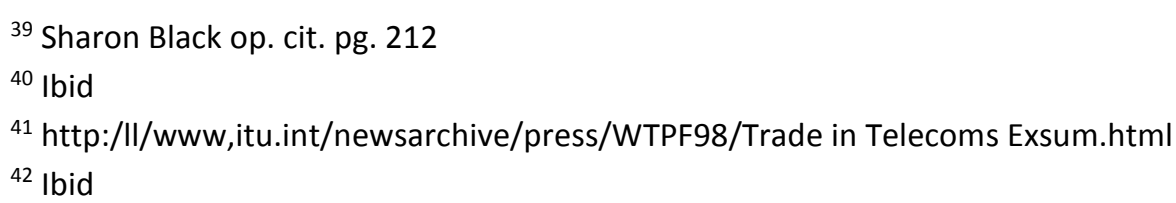


and international operating agencies, access to network and service directives, both domestically and internationally, provision of administrative information enabling call costs to be mentioned and checked.

Fourthly, measures relating to access to services: are designed to increase the number of services available in a country and to spread their use through appropriate development of a supply adapted to users' specific expectations, particularly for international trade. These measures are based on liberalization of telecommunication services and includes: access to international data transmission services and access to international message services and possible development of a network of intermediaries to market these services, opening up of basic services to competition and development of competition with regard to value-added services possibly on a regional basis, with regulation of access switch boards, establishment of service interconnections, particularly data transmission services, possibility of paying for international services in local currency, development of international roaming agreements for all types of mobile services, when the provision of services seems inadequate in a particular area, improvement of the opportunities for person involved in international trade to negotiation access to services provided from outside locations, progressive decentralization of special access within countries and preparation of specification for all the communication applications described.

Furthermore, the Electronic Communication Commission should formulate policies that will encourage its member states to remove as much as possible, every obstacles and barriers that tends to hinder the growth and development in the use of international telecommunications in international trade contracts, such as reduction in tariff rates, removal of obstacles to free movement of telecommunication network facilities, and the promotion of easy access to international telecommunication infrastructures.

Moreover, the World Trade Organization (WTO) should also work in collaboration with the Electronic Communications Commission to ensure that international trade contract is promoted with greater efficiency across the world, by ensuring that international telecommunications is relied on and used as a necessary facility for all international trade contracts.

\section{CONCLUSION}

Telecommunications is indeed an indispensable mechanism for business transactions and communications, both nationally and internationally. This has proven to be the fact in international trade contracts, as discussed earlier. International telecommunications has enhanced the establishment of trans-national trade contracts, by making it possible for countries, companies and individuals in such countries to advertise, introduce and export their trades in goods and services to individuals, companies and governments of other countries. This can be seen through the establishment of bilateral and multilateral international trade contracts. In addition to facilitating international trade contracts, trade in telecommunications services and infrastructure is one of the fastest growing trades in the world due to its enormous rate of consumption. This accounts for the desire to systematically co-ordinate and regulate the use of telecommunication services in international trade contracts. This can be seen from the aims and objective of the Electronic Communication Convention (ECC).

It is obvious that the importance of international trade in telecommunications, international telecommunications and international trade contracts is becoming more pronounced by the day, due to the facilities and infrastructures put on ground by modern technology to promote these monumental achievements. There is therefore absolute need to give effect to the recommendations for optimal utility of telecommunications in international contract. 